Canadian Science Publishing

Canadian Journal of Earth Sciences Revue canadienne des sciences de la Terre

\title{
An Eocene brontothere and tillodonts (Mammalia) from British Columbia, and their paleoenvironments
}

\begin{tabular}{|r|l|}
\hline Journal: & Canadian Journal of Earth Sciences \\
\hline Manuscript ID & cjes-2017-0061.R1 \\
\hline Manuscript Type: & Article \\
\hline Date Submitted by the Author: & $18-$ May-2017 \\
\hline $\begin{array}{r}\text { Complete List of Authors: } \\
\text { Is the invited manuscript for } \\
\text { consideration in a Special } \\
\text { Issue? : }\end{array}$ & N/A \\
\hline Keyword: & Eocene, brontothere, tillodont, paleoflora, British Columbia \\
\hline &
\end{tabular}


1 An Eocene brontothere and tillodonts (Mammalia) from British Columbia, and their 2 paleoenvironments.

3 Jaelyn J. Eberle, and David R Greenwood

4 5

6

7

8

9

10

11

12

16 Jaelyn J. Eberle, University of Colorado Museum of Natural History and Department of

17 Geological Sciences, University of Colorado at Boulder, 265 UCB Boulder, CO 80309, U.S.A.;

18 David R. Greenwood, Department of Biology, Brandon University, J.R. Brodie Science Centre, 19 270-18th Street, Brandon, MB R7A 6A9, Canada.

20

21

22

23 Corresponding author: Jaelyn J. Eberle (email: Jaelyn.Eberle@Colorado.edu) 
24 An Eocene brontothere and tillodonts (Mammalia) from British Columbia, and their

25 paleoenvironments.

26 Jaelyn J. Eberle, and David R Greenwood

\section{Abstract:}

28 We describe Eocene fossils of the tillodont Trogosus from the Allenby Formation in Princeton,

29 British Columbia (B.C.) as well as teeth of Brontotheriina from the lower Australian Creek

30 Formation near Quesnel, B.C. These fossils represent the only occurrence of Tillodontia and

31 Brontotheriidae in B.C. Further, the presence of the largest species of Trogosus - T. latidens - as

32 well as a smaller species identified only as Trogosus sp. supports a late early - early middle

33 Eocene (Bridgerian) age for the Vermilion Bluffs Shale of the Allenby Formation. Based on their

34 morphology and large size, the teeth referred here to Brontotheriina represent one of the larger,

35 more derived brontothere genera, and suggest a Uintan - Chadronian (middle - late Eocene) age

36 range for the lower Australian Creek Formation that is consistent with radiometric ages of

37 underlying volcanic rocks. Paleobotanical data from sediments correlative to those that produced

38 these Eocene mammal fossils suggest they inhabited forested landscapes interspersed with

39 swamps and open water environments, under mild and wet temperate climates (MAT $\sim 10-16{ }^{\circ} \mathrm{C}$;

$40 \mathrm{CMMT}-4-4{ }^{\circ} \mathrm{C}$; MAP $>100 \mathrm{~cm} / \mathrm{yr}$ ). These mixed conifer-broadleaf forests included tree genera

41 typical of modern eastern North American forests (e.g., Tsuga, Acer, Fagus, and Sassafras),

42 together with genera today restricted to east Asia (e.g., Metasequoia, Cercidiphyllum, Dipteronia,

43 and Pterocarya). The paleobotanical evidence is consistent with the hypothesized habitats of

44 both tillodonts and brontotheres. 


\section{Introduction}

46 The Eocene Epoch (ca. 56 - 33.9 Ma; Cohen et al. 2013) saw significant global climate

47 change, including a pulse of hyperthermals near its onset that marked the height of global

48 warming since dinosaur extinction (Zachos et al. 2008). Cooling began in the middle Eocene and

49 culminated in a significant global temperature drop and rapid expansion of continental ice sheets

50 on Antarctica near the Eocene-Oligocene boundary - the transition from a greenhouse to an

51 icehouse (Miller et al. 1987; Zanazzi et al. 2007 and references therein). Importantly, North

52 America saw major reorganization of its mammalian fauna in the early Eocene, marked by

53 appearance of Perissodactyla, Artiodactyla, hyaenodontid creodonts, and Euprimates at its onset

54 and multiple dispersal events throughout the Eocene (Beard 1998), while the end of the Eocene

55 marked extinction in marine and terrestrial realms, although the North American mammalian

56 fauna was largely unaffected (Zanazzi et al. 2007). Most of what we know about the North

57 American fauna and flora during the Eocene comes from localities in the U.S. Western Interior,

58 although discoveries in the Canadian Arctic have shed light on early - middle Eocene polar

59 fauna and flora (Dawson et al. 1976; Eberle and Greenwood 2012 and references therein), and

60 Saskatchewan's Cypress Hills Formation has produced late Uintan - Chadronian (middle - late

61 Eocene) mammalian faunal assemblages (Robinson et al. 2004 and references therein; Prothero

62 and Emry 2004). In British Columbia, whereas its Eocene flora and insect fauna have been

63 studied since the 1890s (e.g., Dawson 1883, 1890; Archibald et al. 2010; Greenwood et al. $2016 a$

64 and references therein), the Eocene mammalian fauna is poorly known.

65 Eocene mammals are rare in British Columbia. The most taxonomically diverse fauna,

66 with some seven orders represented, is from the Kishenehn Formation cropping out along the

67 North Fork in southern B.C., and is tentatively assigned a latest Eocene (Chadronian) age 
68 (Constenius et al. 1989; M.R. Dawson (personal communication to JE, 2017)). Outside of the

69 Kishenehn, however, the number of Eocene mammal fossils in B.C. drops dramatically. Russell

70 (1935) briefly described one and a half tillodont lower molars from a coal mine in the Allenby

71 Formation near Princeton, referring them to "Trogosus minor" (a species that is no longer valid),

72 while Gazin (1953) noted a second tillodont specimen from Princeton. An undescribed jaw of an

73 erinaceid (hedgehog family) is purported to have also come from the Princeton area (Mathews

74 and Monger 2005, pp. 229-230), although the specimen appears to be lost. Further north, near

75 Quilchena, a fragment of a tiny lower molar (Q5508, Simon Fraser University) of an

76 indeterminate lipotyphlan was collected by Glen Guthrie in the early 1990s from the west side of

77 Quilchena Creek in strata of the Coldwater Formation that also preserve a diverse flora and

78 insect fauna, fossil fishes, and rare fossil feathers (Mathewes et al. 2016). Brontothere teeth were

79 collected from the lower Australian Creek Formation near Quesnel in central B.C., though never

80 described (Rouse and Mathews 1979). Ludvigsen (2001) reported postcranial material of a small

81 mammal from Driftwood Canyon Provincial Park near Smithers, northern B.C. (Fig. 1), but in

82 the absence of cranial and dental remains this specimen is probably unidentifiable. More recently,

83 Eberle et al. (2014) described two fossil mammals - the erinaceid Silvacola acares and the

84 tapiroid cf. Heptodon from an unnamed formation of the Eocene Ootsa Lake Group (coined the

85 Driftwood Creek beds) in Driftwood Canyon Provincial Park. These fossils are the first early

86 Eocene (Wasatchian) mammals from mid-latitude Canada, although a diverse late Wasatchian

87 mammal fauna is known from Ellesmere Island (Dawson et al. 1976; Eberle and Greenwood

88 2012).

89 Here, we describe the tillodont fossils from Princeton and the brontothere teeth from

90 Quesnel. The presence of both groups refine the age of the strata, and are the first records of 
91 Tillodontia and Brontotheriidae from British Columbia. Tillodontia are a small group of

92 medium- to large-sized archaic herbivores that range in age from the late Paleocene to the middle

93 Eocene in North America. They appear earlier in the Paleocene in Asia and are hypothesized to

94 have originated on that continent and crossed into North America via Beringia by late Paleocene

95 time (Stucky and Krishtalka 1983; Miyata 2007a and references therein). Their distinctive tooth

96 morphology, considered alongside skeletal anatomy, suggests tillodonts were diggers that fed on

97 tough vegetation, roots, and tubers that introduced soil and grit to their diet, which may account

98 for the heavy wear on their teeth (Lucas and Schoch 1998; Rose 2006). The fossils from B.C. are

99 the only undoubted occurrence of tillodonts in Canada, although a small piece of tusk from

100 Ellesmere Island, Nunavut may belong to the group (Schoch 1986; M.R. Dawson (personal

101 communication to Eberle, 2017)).

102 The Brontotheriidae is a clade of medium- to very large-sized browsers that inhabited

103 North America and Asia throughout the Eocene, going extinct at the Eocene-Oligocene boundary

104 (Mihlbachler 2008). By latest Eocene time, they had evolved into giant horned forms comparable

105 in size to large rhinos. Stratigraphically the earliest known occurrence of North American

106 brontotheres is from Arctic Canada, where their fossils occur in late Wasatchian and early

107 Bridgerian-aged strata of the Margaret Formation on Ellesmere Island (Eberle 2006; Eberle and

108 Eberth 2015). Like the tillodonts, the clade was hypothesized to have originated in Asia and

109 dispersed across Beringia into North America (Beard 1998), although recently others have

110 suggested the reverse - a North American origin and subsequent dispersal into Asia (Mihlbachler

111 2008). That early forms occur in Arctic Canada suggests that at least some brontotheres were

112 adapted to Arctic environments, supporting the hypothesis for trans-Beringian dispersal during

113 early and middle Eocene time (Eberle and Eberth 2015). The brontothere teeth from Quesnel are 
114 the only documented occurrence of brontotheres in B.C. and belong to one of the larger,

115 geologically younger taxa (discussed below).

116 To place these Eocene mammals from British Columbia into a paleoenvironmental context,

117 we also summarize available paleobotanical data for the associated sediments to reconstruct the 118 paleoclimate, and present a new analysis of the paleoclimate of the Australian Creek Formation.

120 Geologic Setting

121 Princeton Basin - Allenby Formation.

122 The tillodont fossils described below come from the Allenby Formation in the Princeton

123 Basin, which extends in a north-south axis from just north of the town of Princeton B.C. (Fig. 1),

124 paralleling the Similkameen River. A minor associated coal basin (Tulameen Basin) occurs to

125 the west near the towns of Tulameen and Coalmont. The prevailing major rock units of the

126 Princeton Basin - the Princeton Group - are composed of up to $1370 \mathrm{~m}$ of volcanic rocks, and a

1271600 to $2100 \mathrm{~m}$ thick sedimentary sequence containing major coal seams, shales, and sandstones

128 together with minor volcanics (Shaw 1952; McMechan 1983; Read 1987, 2000). The Princeton

129 Basin is considered to be formed within a complex half graben, with structural features including

130 major faults, synclines and anticlines, indicating a complex structure that included considerable

131 volcanic activity during its formation (McMechan 1983). The depositional low was likely a

132 consequence of crustal extensional activity associated with the uplift of the Rocky Mountains

133 and the underplating of rafted terranes (McMechan 1983; Ickert et al. 2009).

134 Shaw (1952) divided the Princeton Group into a Lower Volcanic Formation, the Allenby

135 Formation, and an Upper Volcanic Formation. McMechan (1983) divided the predominantly

136 sedimentary Allenby Formation into three informal members - the volcanic, lower, and coal- 
137 bearing members - and provided correlation data for the major coal seams mined in the

138 Princeton Basin. Read $(1987,2000)$ further refined the stratigraphic framework of the Allenby

139 Formation, subdividing it into 14 units, including (in ascending stratigraphic order) the Hardwick

140 Sandstone, Vermilion Bluffs Shale, Summers Creek Sandstone, and the uppermost Ashnola

141 Shale (Fig. 2). Read's (1987, 2000) nomenclature is followed here. The tillodont fossils, as well

142 as most of the coal mined from the Princeton Basin, came from seams that are part of the

143 Vermilion Bluffs Shale (Read 2000). The coal seam mined in Pleasant Valley Mine \#2 (= Wilson

144 Mine) is the Princeton \#1 seam, which is the Princeton basin $0 \mathrm{~m}$ datum used by McMechan

145 (1983) and Read (1987, 2000). Read (2000) stated for the Pleasant Valley Mine \#2 that the

146 Princeton \#1 seam is $140 \mathrm{~m}$ below the top of the Vermilion Bluffs Shale. The published section

147 for Pleasant Valley Mine \#2 (Shaw 1952; McMechan 1983) shows a thickness of about 2.5m of

148 coal with two shale partings, an underlying sandstone, and the top of the mined seam grading

149 into a shaly-coal at about 2.6-3.0m above the base of the Princeton \#1 seam. The Thomas Ranch

150 megaflora (Dillhoff et al. 2013) corresponds to fossil locality F25 in Read (1987, Table 4A), in

151 the Vermilion Bluffs Shale, up-section from the Princeton \#1 seam.

152 The age of the Allenby Formation and the fossil assemblages reported from the formation

153 have been problematic, with earlier reports stating Miocene, Oligocene, or Eocene (e.g., Dawson,

154 1890; Penhallow 1908; Russell 1935; Shaw 1952; Arnold 1955b). Early K-Ar dates of 50 Ma,

155 combined with palynology and mammalian biostratigraphy (specifically the tillodont fossils),

156 were correlated using the geochronometric scales in use at the time to place the Allenby

157 Formation as Middle Eocene (Hills and Baadsgaard 1967). However, based on the current

158 geochronometric scale, the early-middle (Ypresian-Lutetian) Eocene boundary is at 47.8 Ma

159 (Cohen et al. 2013), placing the Allenby Formation as early Eocene (Ypresian) based on the 
160 older K-Ar dates (Fig. 2). More recent ${ }^{40} \mathrm{Ar} /{ }^{39} \mathrm{Ar}$ and $\mathrm{U}-\mathrm{Pb}$ dates from Allenby Formation

161 volcanics are even older, at 52 Ma (e.g., Moss et al. 2005; Ickert et al. 2009; summarized in

162 Greenwood et al. 2016a), with the top of the Allenby Formation likely 48.7 Ma based on an

163 unpublished date for Ash \#22 in the Princeton Chert (Little et al. 2009; Pigg et al. 2016). Moss et

164 al. (2005) reported an unpublished age using U-Pb from zircons for the Vermilion Bluffs Shale at 165 Hospital Hill in the town of Princeton as $52.08 \pm 0.12 \mathrm{Ma}$, which is consistent with an ${ }^{40} \mathrm{Ar} /{ }^{39} \mathrm{Ar}$ 166 age of $52.0 \pm 1$ Ma for the overlying Sunday Creek Sandstone of Read $(1987,2000)$ by Ickert et

167 al. (2009).

168

169 Quesnel area - Australian Creek Formation.

170 The valley of the Fraser River around Quesnel in central B.C. (Fig. 1) preserves a series of 171 outcrops exceeding $320 \mathrm{~m}$ of extrusive volcanic rocks and minor sediments correlative with the

172 Eocene Kamloops Group to the south, but more recently mapped as the Eocene Endako Group

173 (Piel 1971; Rouse and Mathews 1979; Hora and Hancock 1994; Massey et al. 2005; Bordet et al.

174 2014). These rock units are capped by a series of mostly sedimentary rocks of the Australian

175 Creek Formation initially considered to be early Oligocene in age, and the Miocene Fraser Bend 176 and Crownite formations, overlain by late Miocene sheet basalts of the Neogene Chicoltin Group.

177 These rock units are in turn capped by Pleistocene sediments (Rouse and Mathews 1979; Hora 178 and Hancock 1994; Bordet et al. 2014) (Fig. 3). Initial K-Ar ages for the volcanics of the 179 Kamloops Group in the Quesnel area ranged from 48.8 $\pm 1.5 \mathrm{Ma}$ to 41.6 $\pm 1.9 \mathrm{Ma}$ (Rouse and 180 Mathews 1979) (Fig. 2), although these rocks are now mapped as Endako Group, which has $181{ }^{40} \mathrm{Ar} /{ }^{39} \mathrm{Ar}$ ages ranging from 51-45 Ma (Grainger et al. 2001; Bordet et al. 2014). Extensive 
182 slumping of the Miocene Fraser Bend and Crownite formations obscures local stratigraphic 183 sequences (Rouse and Mathews 1979; Hora and Hancock 1994) (Fig. 3).

184 The approximately $500 \mathrm{~m}$ thick Australian Creek Formation was defined by Rouse and 185 Mathews (1979) from a section near the confluence of Australian Creek and the Fraser River. 186 The brontothere teeth (ROM 6088) were recovered from the lower part of the formation, at the 187 base of a coal seam near river level, on the west side of the Fraser River approximately $35 \mathrm{~km}$ 188 south of Quesnel (K. Seymour (personal communication to JE, 2017)). The lower part of the 189 formation is composed of claystones and mudstones, silty to sandy lenses, and lignite seams, 190 while the upper part is predominantly conglomerate and pebbly sandstones containing volcanic 191 clasts (Rouse and Mathews 1979) (Fig. 3).

192 The Australian Creek Formation was deposited in lacustrine, fluviatile and paludal settings 193 of a lowland floodplain in a graben or half graben. Minor occurrences of fossil leaves have been 194 reported from a clay beneath a breccia west of Quesnel (Rouse and Mathews 1979), and a series 195 of samples from the lower beds of the Australian Creek Formation include a microflora that has 196 been described (Piel 1971; Rouse and Mathews 1979). The early Oligocene age assignment of 197 the Australian Creek Formation is based in part on diagnostic palynomorphs in these microfloras 198 (Piel 1971; Rouse and Mathews 1979), and the identification of the brontothere ('titanothere' in 199 these reports) from the lower beds of the Australian Creek Formation as suggesting a Chadronian 200 age (Piel 1971; Rouse and Mathews 1979; Hora and Hancock 1994). Under the current 201 geochronology for the North American Land Mammal Ages (NALMA), however, the 202 Chadronian is late Eocene (Prothero and Emry 2004 and references therein) (Fig. 2). 
205

206

207

208

209

210

211

212

213

214

215

216

217 218

219

220

221

222

223

224

225

226

227

\section{Vertebrate paleontology}

The tillodont fossils described here were recovered from the Pleasant Valley Mine \#2, also called the W.R. Wilson Coal Mine, near Princeton, B.C. in the 1930s. According to its associated catalog card (dated December 2 1934), the larger and more complete specimen CMN 8709 came from the.... 'mouth of mine 430 feet below surface', whereas CMN 8687 (= GSC 8687) was collected by B.R. MacKay and C. Stubbs from the W. R. Wilson Mine in 1933. Based on the stratigraphic nomenclature of Read $(1987,2000)$, the sediments that hosted the coal seam mined in the Pleasant Valley Mine \#2 are part of the Vermilion Bluffs Shale, with the coal being the Princeton \#1 seam (Table 5 in Read 1987). Read (1987, Table 4A) indicated that the tillodont was collected from the Vermilion Bluffs Shale.

The brontothere teeth (ROM 6088) were collected in the 1960s by G.E. Rouse from the west bank of the Fraser River, $2.5 \mathrm{~km}$ south of the mouth of Australian Creek (UTM grid 349390; Rouse and Mathews 1979, appendix 1); the specimen is curated at the Royal Ontario Museum (ROM).

Identifications of the tillodont specimens were made via comparison with specimens in the University of Colorado Museum of Natural History (UCM) Fossil Vertebrate Collection as well as published descriptions and images, while the brontothere teeth were compared to specimens at the University of California Museum of Paleontology (UCMP) and UCM.

Tillodont dental terminology follows Bown and Kraus (1979) and Miyata (2007b, fig. 1). We follow brontothere dental terminology outlined by Osborn (1929, fig. 221) and Mihlbachler (2008, fig. 4). Dental measurements were obtained using Mitutoyo Absolute Digimatic digital calipers. Brontothere classification follows Mihlbachler (2008), while tillodont classification follows Lucas and Schoch (1998). 
Institutional abbreviations-AMNH, American Museum of Natural History, New York,

229 U.S.A.; CMN; Canadian Museum of Nature, Ottawa, ON; GSC, Geological Survey of Canada,

230 Calgary, Canada; ROM Royal Ontario Museum, Toronto, ON; UCM, University of Colorado

231 Museum of Natural History, Boulder, CO; UCMP, University of California Museum of

232 Paleontology, Berkeley, CA, YPM, Yale Peabody Museum, New Haven, CT.

233 Dental Terminology - L, Left; R, Right; P/p, upper/lower premolar; M/m, upper/lower

234 molar, A-P length, Anteroposterior length; Wtri, Trigonid Width; Wtal, Talonid Width.

235

236 Paleobotanical climate reconstruction

237 For the Allenby Formation, we compiled available reports of fossil flora attributed to the

238 Vermilion Bluffs shale of Read $(1987,2000)$ to provide an account of the paleovegetation and

239 paleoclimate. In particular, Dillhoff et al. (2013) provided a detailed systematic appraisal of the

240 Thomas Ranch flora, which was collected from within the Vermilion Bluffs shale on the north

241 bank of the Tulameen River, proximal to Pleasant Valley Mine \#2. These authors also provided

242 estimates of annual temperature and precipitation as well as seasonal values, based on both a

243 nearest living relative (NLR) analysis and leaf physiognomy. As only microflora is described in

244 detail for the Australian Creek Formation, we applied the same NLR approach to the flora (Table

245 1) as used by Dillhoff et al. (2013) to allow comparability of the data.

246 In the NLR method, fossil plant taxa have their nearest living relative identified and the

247 climate limits of all identified NLRs are compared to find the zone of overlap where all taxa can

248 co-exist. Dillhoff et al. (2013) used a variant of the NLR method, bioclimatic analysis

249 (Greenwood et al. 2005), where the estimate is derived using the $10^{\text {th }}$ and $90^{\text {th }}$ percentiles of the

250 assemblage of NLRs to weight against so-called outliers, taxa whose climate range may fall 
251 outside the range of the majority of other NLRs. The estimate is expressed as the midpoint of the

252 maximum and minimum estimates, with the full range of the estimate expressed as an

253 uncertainty value (Greenwood et al. 2005; Thompson et al. 2012; Mathews et al. 2016). Climate

254 range data for modern plant genera identified as NLRs used in our analysis (Table 1) were

255 derived principally from Thompson et al. (2012) and Fang et al. (2011), with additions as

256 described in Mathewes et al. (2016). Recent analyses of the NLR method for North American

257 plant taxa show that estimates derived from plant genera are accurate (Thompson et al. 2012;

258 Harris et al. 2017).

259

260 Systematic Paleontology

261 Order Tillodontia Marsh, 1875

262 Family Esthonychidae Cope, 1883

263 Subfamily Trogosinae Gazin, 1953

264 Trogosus Leidy, 1871

265

266 Comments: Trogosus was a large, derived tillodont primarily known from the late early - early

267 middle Eocene of western North America, but also known from Asia (Miyata 2007a). and

268 considered an index taxon for the Bridgerian North American Land Mammal Age (Robinson et

269 al. 2004). It was a stout, bear-like herbivore that weighed $150 \mathrm{~kg}$ or more, it had a short neck and

270 long tail, large claws on its manus, a long rostrum and deep mandible, and its second incisors

271 were large evergrowing tusks (Lucas and Schoch 1998; Miyata 2007a, b). Trogosus is

272 hypothesized to have used its large tusks and claws to dig up roots and tubers, and this appears to

273 be borne out by the heavy wear on most Trogosus dentitions, suggesting that it ingested soil and 
274 grit while eating (Gingerich and Gunnell 1979). Four to six North American species of Trogosus

275 are considered valid, diagnosed primarily by cranial, mandibular, and dental characters (Miyata

276 2007a, b; Lucas and Schoch 1998). It is arguably the best-known tillodont, and is considered an

277 index taxon for the Bridgerian North American Land Mammal Age (Robinson et al. 2004).

278

279 Trogosus latidens (Marsh, 1874)

280 Figure 4, Table 2

281

282 REFERRED SPECIMEN: CMN 8709, mandibular fragment with worn Lm1-3 and Rm2.

284 LOCALITY: CMN 8709 was recovered from the Princeton \#1 coal seam at the mouth of the 285 Pleasant Valley Mine \#2 (=W.R. Wilson Coal Mine), near Princeton, B.C. The coal seam is part 286 of the Vermilion Bluffs Shale, Allenby Formation, Princeton Basin, B.C.

KNOWN DISTRIBUTION: Huerfano Formation, CO; Aycross Formation, Big Horn Basin, WY;

289 Bridger Formation, Green River Basin, WY; Vermilion Bluffs Shale, Allenby Formation, 290 Princeton Basin, B.C. (all Bridgerian).

292 DESCRIPTION AND DISCUSSION: CMN 8709, which comprises a mandibular fragment with 293 worn Lm1-3 and Rm2 (Fig. 4), was collected in the 1930s from the mouth of the Pleasant Valley 294 Mine \#2 near Princeton, B.C. It was identified in 1934 as "Trogosus minor" ( = nomen dubium; 295 Gazin 1953), but subsequently Gazin (1953) tentatively identified it as ?Trogosus latidens due to 296 its large size, although didn't describe the specimen. T. latidens is known primarily from isolated 
297 cheek teeth, and is diagnosed only by its large size (Gazin 1953; Gunnell et al. 1992). More

298 recently, Miyata's (2007a) analysis of the size range of T. latidens, that included measurements

299 of a cast of CMN 8709, concluded that lower molars referred to T. latidens are $25 \%$ longer and

300 wider than those of other North American species of Trogosus.

301 As noted for tillodonts in general, the mandible on CMN 8709 is deep, and the trigonid

302 and talonid on the molars are U-shaped. Although the teeth exhibit considerable wear (e.g., the

303 smallest molar, Lm1, is completely worn, save for the posterolabial corner of the tooth), the

304 trigonid is nonetheless taller than the talonid on each of the molars. The $\mathrm{m} 2 \mathrm{~s}$ and $\mathrm{m} 3 \mathrm{on} \mathrm{CMN}$

3058709 show that the paraconid was as lingual as the metaconid, and the latter is the tallest cusp on

306 the tooth on $\mathrm{m} 3$, although this may be related to the heavy wear over the rest of the tooth. A short

307 metastylid occurs posterior to the metaconid on $\mathrm{Lm} 2$ and $\mathrm{m} 3$. A short, heavily worn entoconid is

308 present on the $\mathrm{Lm} 2$ and $\mathrm{m} 3$, though this region is completely worn down on the Rm2. The $\mathrm{m} 3$

309 talonid is incomplete, and consequently the presence of a third lobe basin cannot be ascertained.

310 The cristid obliqua joins the posterior wall of the trigonid lingual of the anteroposterior midline

311 of the tooth.

312

313 Trogosus sp.

314 Figure 4

315

316 REFERRED SPECIMEN: CMN 8687, a Lm1 talonid fragment and nearly complete Lm2. 
318 LOCALITY: CMN 8687 was recovered in 1933 from the Princeton \#1 coal seam at the mouth of 319 Pleasant Valley Mine \#2 (=W.R. Wilson Coal Mine) near Princeton, B.C. The coal seam is part 320 of the Vermilion Bluffs Shale, Allenby Formation, Princeton Basin, B.C.

321 DESCRIPTION AND DISCUSSION: CMN 8687, a Lm1 talonid fragment and nearly complete 322 Lm2, was briefly described and referred to "Trogosus minor" by Russell (1935). However, 323 "Trogosus minor" was disregarded as a valid species by Gazin (1953) because the type (YPM 324 11083, a Rm2) cannot be differentiated from $\mathrm{m} 2$ of T. hyracoides or T. castoridens. Gazin (1953) 325 further suggested that T. hyracoides and T. castoridens may represent morphologic variants of 326 the same species (perhaps males and females), although some workers have since considered 327 both species valid (e.g., Miyata 2007a, b; Miyata and Deméré, 2016; but see Lucas and Schoch 328 1998).

329 CMN 8687 is unusual for a tillodont fossil in that the teeth are essentially unworn (Fig. 4).

330 The $\mathrm{m} 1$ on CMN 8687 consists only of the labial part of the talonid which preserves a large 331 hypoconid, whereas the $\mathrm{m} 2$ is nearly complete, missing only its paraconid and part of the labial 332 wall of the talonid. The $\mathrm{m} 2$ on CMN 8687 has a length of $20.0 \mathrm{~mm}$, WTri of $17.8 \mathrm{~mm}$, and WTal 333 of $16.1 \mathrm{~mm}$, placing it within the size range of $\mathrm{m} 2 \mathrm{~s}$ of $T$. castoridens and T. hyracoides measured 334 by Gazin (1953) and T. grangeri measured by Robinson (1966).

335 On the $\mathrm{m} 2$ of CMN 8687, the labial cusps and lophids of the trigonid and talonid form a 336 U-shaped pattern in occlusal aspect, as in CMN 8709, but unlike Trogosus gazini from the 337 Bridger Formation in Wyoming in which the talonid on m1-m2 is V-shaped (see Miyata 2007b).

338 On the $\mathrm{m} 2$ of $\mathrm{CMN} 8687$, the trigonid is noticeably taller than the talonid, and comparable in 339 relative height and hypsodonty to an $\mathrm{m} 1$ of Trogosus hillsii (UCM 69094) from the Huerfano 340 Formation in Colorado; both are more hypsodont than lower molars of T. gazini that Miyata 
341 (2007b) described as relatively brachydont. Although the paraconid has been broken off, the m2

342 on CMN 8687 preserves a large protoconid (the largest cusp on the tooth), and a metaconid that

343 is subequal in height and posterolingual to the protoconid. A crenulated protolophid runs

344 between the proto- and metaconids. CMN 8687 bears a well-developed metastylid posterior to,

345 and lower than, the metaconid, contrasting T. gazini which has a weak metastylid (Miyata

346 2007b). The talonid basin of the $\mathrm{m} 2$ on $\mathrm{CMN} 8687$ is deeper than the trigonid basin, and is open

347 lingually with a deep notch occurring on the lingual margin between the metastylid and

348 entoconid. The $\mathrm{m} 2$ on CMN 8687 lacks a precingulid, although it has a weak discontinuous

349 cingulid on the posterolabial margin of the $\mathrm{m} 2$ talonid. Like $\mathrm{m} 2 \mathrm{~s}$ of some other trogosines,

350 including some specimens of T. latidens (UCM 42723) and Tillodon fodiens (see Miyata 2007b),

351 the $\mathrm{m} 2$ on CMN 8687 has a small second talonid basin - the hypoconulid-entoconid basin -

352 although the basin is not completely closed in that a notch exists along its lingual margin directly

353 posterior to the entoconid. The second talonid basin does not appear to be restricted to $\mathrm{m} 2 \mathrm{~s}$ of

354 Trogosus, as UCM 69094, an $\mathrm{m} 1$ referred to T. hillsii, also shows the feature.

355 According to Gazin (1953), molars of T. castoridens and T. hyracoides are comparable in

356 size, and the primary difference between these two genera relates to the length of the rostrum $-T$.

357 hyracoides has a longer rostrum than T. castoridens. Subsequently, Robinson (1966) suggested

358 that T. grangeri and T. hillsi may be synonymous and had similar-sized upper dentitions. Lucas

359 and Schoch (1998) considered T. hyracoides a junior synonym of T. castoridens, and they

360 synonymized T. hillsi with T. grangeri, following Robinson (1966). Recently, Miyata and

361 Deméré (2016) suggested that $T$. castoridens and T. hyracoides as well as T. hillsi and T.

362 grangeri represented sympatric pairs of short- and long-faced species in the Green River and

363 Huerfano basins, respectively, although this idea, initially put forward by Gazin (1935), has been 
364 questioned due to small sample size and the fragmentary nature of most Trogosus fossils.

365 Concerning the identification of CMN 8687, it seems too small to be T. latidens, and it is

366 morphologically distinct in a number of characters from $T$. gazini. However, due to the overlap

367 in size and morphology of lower molars of the other species and questions concerning

368 synonymies, we cannot refer CMN 8687 to any previously known species of Trogosus, and as

369 such refer the specimen only to Trogosus sp.

370

371 Order Perissodactyla Owen, 1848

372 Family Brontotheriidae Marsh, 1873

373 Subtribe Brontotheriina Marsh, 1873

374

375 Comments: The Brontotheriidae is an Eocene clade of perissodactyls (odd-toed ungulates)

376 known from North America, Asia, and Europe (Mihlbachler 2008 and references therein). They

377 are differentiated from other perissodactyls by several cranial and dental characters, including an

378 elongate postorbital cranium, a short face with the orbit above M2, a W-shaped ectoloph and

379 isolated proto- and hypocones on their upper molars, as well as an M-shaped lophid pattern,

380 reduced paraconid, and large m3 hypoconulid on lower molars. However, the cranial

381 morphology is primarily used to differentiate among the later, larger more derived brontothere

382 genera (Mader 1989; Mihlbachler 2008). With regard to lower molars such as those on ROM

3836088 , primarily size is used to refer this specimen to Brontotheriina - a clade that includes large-

384 bodied, horned brontothere species from North America and Asia (Mihlbachler, 2008).

385

386 Brontotheriina, gen. et. sp. indet. 
Figure 5

DESCRIPTION: ROM 6088, found in the lower Australian Creek Formation cropping out on the west side of the Fraser River approximately $32 \mathrm{~km}$ south of Quesnel, comprises a partial Rm3 (missing its hypoconulid, metaconid, and entoconid) and the talonid of Rm2 (Fig. 5). Although

392 incomplete, the length of $\mathrm{m} 3$ clearly exceeded $63 \mathrm{~mm}$, and the trigonid and talonid widths are 39340.1 and $39.9 \mathrm{~mm}$, respectively; the $\mathrm{m} 2$ talonid was at least $40 \mathrm{~mm}$ wide. Its large size places 394 ROM 6088 within the size range of m3s of latest Eocene (Chadronian) Megacerops spp. and 395 about a mm wider than m3s of late Uintan Eubrontotherium clarnoensis and about 2 mm wider 396 than m3s of Protitanops curryi and Protitanotherium emarginatum measured by Mihlbachler 397 (2008, appendix 1). ROM 6088 is also within the size range of middle Eocene Asian taxa, 398 including Gnathotitan berkeyi, Rhinotitan spp., and Metatitan relictus (Mihlbachler, 2008, 399 appendix 1). Genera within the Brontotheriina are differentiated from one another based largely 400 upon cranial characters, whereas their lower molars are morphologically very similar and overlap 401 in size. Like the lower molars of these taxa, ROM 6088 has shallow trigonid and talonid basins, a 402 ridge-like paraconid, and a notch midway along the lingual margin of the talonid basin. The 403 labial cingulid on ROM 6088 is discontinuous, like Eubrontotherium clarnoensis (see 404 Mihlbachler 2007), although this character seems variable in Megacerops, with most of the 405 UCM specimens from the White River Formation showing a continuous labial cingulid (e.g., 406 UCM 43751 and 94369). The m3 on ROM 6088 differs from m3s of Megacerops from the

407 White River Formation (UCM specimens 43751, 47863, 20504, and 94369) and 408 Eubrontotherium clarnoensis (UCMP 126102) in having a larger, more lingually-projecting 409 metacristid, and the protolophid and cristid obliqua are straight, not bowed or rounded, although 
410 the latter may be a factor of wear (i.e., ROM 6088 is not as worn as most Megacerops specimens

411 with which it was compared). However, presence of a lingually expanded metacristid on $\mathrm{m} 3 \mathrm{~s}$ of

412 Megacerops is variable, with some dentitions from the Cypress Hills Formation in Saskatchewan

413 showing similar development to ROM 6088 (Mihlbachler, pers. comm. to JE, 2017). ROM 6088

414 also bears an entocristid along the lingual margin of the tooth anterior to the entoconid. The

415 entocristid is smaller than the metacristid, which bears a tiny wear facet, and the notch in the

416 talonid basin is between the two. Although the hypoconulid is not preserved on the m3 of ROM

4176088 , the pattern of breakage indicates that it was lingual in placement, as in all Brontotheriidae

418 (Mihlbachler 2008).

419

420 DISCUSSION: Brontotheriina is a subtribe within the family Brontotheriidae that includes

421 several middle - late Eocene, large-bodied genera from North America and Asia (Mihlbachler

422 2008). Compared to the North American genera included within the Brontotheriina, the m2

423 talonid and partial m3 of ROM 6088 are considerably wider than lower molars of middle Eocene

424 Duchesneodus, and fall within (or near) the size range of Megacerops spp., Eubrontotherium

425 clarnoensis, Protitanotherium emarginatum, and Protitanops curryi. With regard to age, these

426 taxa range from late Uintan to Chadronian. Specifically, Eubrontotherium clarnoensis is from

427 the Hancock Quarry in the Clarno Formation, Oregon, which is considered ca. 40 Ma or slightly

428 older, based upon Ar/Ar dates of 39.49 - 39.99 Ma for a welded tuff directly above the Hancock

429 Quarry in the basal John Day Formation (Hanson 1996; Lucas et al. 2004 and references therein).

430 Lucas et al. (2004) also suggested the Hancock Quarry fauna fits best with a late Uintan age,

431 based upon its mixture of North American endemics and Eurasian immigrants. Protitanotherium 
432 emarginatum is from a late Uintan locality in the Uinta Formation in Utah, while both

433 Megacerops and Protitanops are Chadronian (latest Eocene) in age (Mihlbachler 2008).

434

435 Paleoenvironment

436 Princeton Basin - Allenby Formation (tillodont)

437 Megaflora remains from the Allenby Formation in the Princeton area were first reported by

438 Dawson (1890) and Penhallow (1908), and remain under study (Greenwood et al. 2016a, 2016b;

439 Pigg et al. 2016). Fossils discovered in outcrop and in mine tailings in the Princeton Basin

440 include compression fossils of plants in shales and coals (e.g., Thomas Ranch; Dillhoff et al.

441 2014; Greenwood et al. 2016a). Three-dimensionally preserved plant organs occur in silicified

442 peats of the Princeton Chert, part of the Ashnola Shale of Read (1987, 2000), on the east bank of

443 the Similkameen River, south of Princeton (Pigg et al. 2016). The outcrops at Whipsaw and

444 Nine-mile creeks are intersected in the abandoned Blue Flame mine, and are stratigraphically

445 equivalent to the shales and coal seams mined in Pleasant Valley Mine \#2 (McMechan 1983;

446 Read 2000). Geographically close to the Pleasant Valley Mine \#2 and Vermilion Cliff

447 (Vermilion Bluffs of modern works) is the Thomas Ranch fossil locality, part of the Vermilion

448 Bluffs Shale unit of Read (2000) (Dillhoff et al. 2013).

449 Penhallow (1908) listed a range of gymnosperm and angiosperm leaf and fruit taxa from

450 his Tulameen locality, and Arnold (1955a, 1955b) reported on the floating water fern Azolla as

451 well as conifers (Cupressaceae and Pinaceae) from the tailings of the Pleasant Valley mine on

452 the south banks of the Tulameen River. At Thomas Ranch, Dillhoff et al. (2013) reported a

453 comparable list of plant genera as reported by Penhallow (1908) and Arnold (1955b) for

454 Tulameen River and the Pleasant Valley Mine, confirming a common flora across the area for 
455 the time span encompassed by the Pleasant Valley and Princeton \#1 coal seams, but adding a 456 number of key conifer and broadleaf angiosperm genera. Many genera are typical of today's 457 mixed deciduous forests of eastern North America and Asia (Greenwood et al. 2005, 2016b). 458 Dillhoff et al. (2013) reconstructed the Thomas Ranch paleoclimate using bioclimatic analysis of 459 the plant fossils' nearest living relatives as mesothermal and moist, with a mean annual 460 temperature (MAT) of $12.8 \pm 2.5^{\circ} \mathrm{C}$, cold month mean temperature (CMMT) of $-3.9 \pm 4.1^{\circ} \mathrm{C}$, 461 and mean annual precipitation (MAP) of $115 \pm 39 \mathrm{~cm} / \mathrm{yr}$ ); slightly cooler temperatures were 462 estimated by Dillhoff et al. (2013) from leaf physiognomy (MAT 9.0 $\pm 2.0^{\circ} \mathrm{C}$ and CMMT $-1.2 \pm$ $\left.463 \quad 3.4^{\circ} \mathrm{C}\right)$.

464 Quesnel area - Australian Creek Formation (brontothere).

465 J.W. Dawson (1877), G.M. Dawson (1883) and Penhallow (1908) reported megaflora from 466 the confluence of the Quesnel and Fraser rivers, from strata Rouse and Mathews (1979) later 467 correlated with their Australian Creek Formation. Taxa included maples (Acer), birch (Betula), 468 hickory (Carya), chestnut (Castanea), beech (Fagus), walnut (Juglans), sycamores (Platanus), 469 oaks (Quercus) and conifers (likely Metasequoia). No recent studies have been made of the plant 470 fossils from the sediments from which the brontothere fossils were collected. However, Piel 471 (1971) and Rouse and Mathews (1979) provided lists of spores and pollen found in lignite and 472 clays of the Australian Creek Formation near the confluence of the Narcolsi and Fraser Rivers 473 (Table 1) near where the brontothere teeth were collected and at another nearby outcrop. Rouse 474 and Mathews (1979) reported a limited megaflora in the clays of the Australian Creek Formation, 475 including Equisetum and leaves of beech (Fagus), oak (Quercus), katsura (Cercidiphyllum), and 476 leafy shoots of the conifer Metasequoia. 
A diverse tree and herbaceous plant microflora is reported from the Australian Creek

478 Formation, including both terrestrial and aquatic forms (Piel 1971; Rouse and Mathews 1979).

479 The tree pollen flora included the conifer families Cupressaceae and Pinaceae (Table 1). Piel

480 (1971) listed several bisaccate grain types he identified as Podocarpus (Podocarpaceae);

481 however, these grains more likely represent extinct Pinaceae (Greenwood et al. 2013 and

482 references therein). The Pinaceae genera present in the pollen flora are all dryland forest trees

483 typical of western Canada and montane areas across North America (i.e., Abies / fir, Picea /

484 spruce, Pseudotsuga / Douglas fir, and Tsuga / hemlock), although black spruce (Picea mariana)

485 is more typical of treed fens in present-day boreal forests. The Cupressaceae recorded by Piel

486 (1971) (Table 1, e.g. Glyptostrobus, Metasequoia, and Taxodium) are today associated with

487 swamp forest environments, with all but Taxodium restricted today to eastern Asia. Similarly, the

488 umbrella pine Sciadopitys found in the samples, is today restricted to Japan, whereas Cedrus is

489 Eurasian in distribution. Rouse and Mathews (1979) also recorded Sequoia (California redwood)

490 in blue-grey clays they associated with stable bottomlands.

The broadleaf tree (i.e., angiosperm) pollen flora from the Australian Creek Formation

492 (Table 1) includes temperate forest genera typical of southeastern North American and east

493 Asian deciduous forests, but also genera restricted today to eastern Asia (e.g., Engelhardia and

494 Pterocarya, both Juglandaceae). Included in the angiosperm pollen flora were swamp trees and

495 shrubs (e.g., alders / Alnus, tupelo / Nyssa), as well as aquatic herbaceous plants (e.g., water

496 primrose / Jussiaea-Ludwigia, and the pond weed / Potamogeton). The understorey of the

497 dryland forests and wetland margins likely were rich in mosses and ferns, including Equisetum

498 (horsetails) and Osmunda (royal fern and similar species) (Table 1). 
Rouse and Mathews (1979) recognized three separate palynofacies in their Australian

500 Creek Formation; the Osmunda facies associated with lignitic clays (peat swamps), a

501 Parviprojectus facies of laminated carbonaceous silts and clays (small lakes and ponds on the

502 alluvial plain), and a Carya facies reflecting weakly bedded blue-grey clays (bottomlands with

503 ponds and backwaters). The overall impression from the spore and pollen flora and the

504 sedimentary facies is of a landscape supporting mixed conifer-broadleaf forests (i.e., mixed

505 mesophytic forest of Rouse and Mathews 1979) interspersed with wetland areas, including treed

506 fens and swamps, and open water. The mixture of genera listed by Piel (1971) and Rouse and

507 Mathews (1979) is consistent with a mesothermal moist climate, with MAT $15-17{ }^{\circ} \mathrm{C}$ and MAP

$508 \quad 100-150 \mathrm{~cm} / \mathrm{yr}$ according to Rouse and Mathews (1979). Applying the same bioclimatic analysis

509 method to the modern plant genera listed in Table 1 as used by Dillhoff et al. (2013) for the

510 Thomas Ranch flora, MAT is estimated at $13.6 \pm 3.0^{\circ} \mathrm{C}$, CMMT $4.0 \pm 4.2^{\circ} \mathrm{C}$, and MAP $129 \pm$

$51134 \mathrm{~cm} / \mathrm{yr}$, consistent with the prior estimates.

512

513 Conclusions

514 With regard to the tillodont fossils described above, Robinson et al. (2004) considered

515 Trogosus an index taxon for the Bridgerian NALMA, which temporally ranges from

516 approximately $51-48 \mathrm{Ma}$ (Smith et al. 2008). Consequently, the relative age inferred for the

517 Vermilion Bluffs Shale based upon presence of Trogosus corroborates the ${ }^{40} \mathrm{Ar} /{ }^{39} \mathrm{Ar}$ and U-Pb

518 age estimates for the Allenby Formation ranging from 52 - $48.7 \mathrm{Ma}$ (Moss et al. 2005; Ickert et

519 al. 2009; Little et al. 2009; Greenwood et al. 2016a; Pigg et al. 2016) (Fig. 2). From a

520 paleobiogeographic perspective, Trogosus latidens and Trogosus sp. from the Eocene of B.C. 
521 support the hypothesis for trans-Beringian dispersal of this genus from Asia into North America

522 during Bridgerian time, initially suggested by Beard (1998).

523 Our inability to assign the brontothere teeth from the lower Australian Creek Formation

524 (ROM 6088) to a known genus has implications for estimating the age of this rock unit, because

525 the late Eocene (Chadronian) age - originally considered early Oligocene based on the

526 geochronology in use for the Chadronian NALMA at the time - assigned to these beds by earlier

527 studies (Rouse and Mathewes 1979) is based largely on the brontothere fossils. Given their size

528 and morphologic similarities with later, larger members of Brontotheriina, the brontothere teeth

529 are consistent with a Chadronian age for the Australian Creek Formation, but they may be as old

530 as late Uintan. The late Uintan - Chadronian NALMA range from 40 - 33.7 Ma (Robinson et al.

531 2004; Prothero and Emry 2004). Volcanic rocks underlying the Australian Creek Formation

532 originally mapped as cf. Kamloops Group south of Quesnel have K-Ar ages of $48.8 \pm 1.5 \mathrm{Ma}$ to

$53341.6 \pm 1.9 \mathrm{Ma}$ (Rouse and Mathews 1979) (Fig. 2). These underlying volcanic rocks are now

534 mapped as the Endako Group (Fig. 3), which has ${ }^{40} \mathrm{Ar} /{ }^{39} \mathrm{Ar}$ ages ranging from 51-45 Ma

535 (Grainger et al. 2001; Bordet et al. 2014). Therefore, the radiometric ages of the rocks underlying

536 the Australian Creek Formation are consistent with a late Uintan - Chadronian age for the

537 brontothere teeth (Fig. 2).

538 Climate and forest character in the area where the tillodont lived during the early Eocene

539 (Dillhoff et al. 2013) were comparable to that reconstructed for the late Eocene brontothere;

540 warm and wet (MAT $12.8 \pm 2.5^{\circ} \mathrm{C}, \mathrm{CMMT}-3.9 \pm 4.1^{\circ} \mathrm{C}$, and MAP $115 \pm 39 \mathrm{~cm} / \mathrm{yr}$ ), supporting

541 mixed conifer-broadleaf forest rich in temperate forest tree genera.

542 The paleoenvironmental reconstruction for the Australian Creek Formation - a warm and

543 wet (MAT $13.6 \pm 3.0{ }^{\circ} \mathrm{C}$, CMMT $4.0 \pm 4.2{ }^{\circ} \mathrm{C}$, and MAP $129 \pm 34 \mathrm{~cm} / \mathrm{yr}$ ) mixed conifer- 
544 broadleaf forest rich in temperate forest tree genera (Table 1) - fits well with the hypothesized

545 habitat of the large late Eocene brontotheres, which based on carbon isotope analysis of their

546 teeth (Zanazzi and Kohn, 2008), were folivores that preferred mesic forested environments.

547

548 Acknowledgements

549 This research was supported by an Explorer Grant (9652-15) from the National Geographic

550 Society to D.R.G., J.J.E. and S. Bruce Archibald. Additional funding was through a Discovery

551 Grant to D.R.G. from the Natural Sciences and Engineering Research Council of Canada. We

552 thank S. Bruce Archibald for his encouragement to explore the potential for further Eocene fossil

553 discoveries in southern British Columbia, Rolf Mathewes (Simon Fraser University) for the loan

554 of the mammal tooth from Quilchena, Kevin Seymour (Royal Ontario Museum) for his loan of

555 the brontothere teeth from the Quesnel area, Richard Hebda (Royal B.C. Museum) for assistance

556 with permits, and Kieran Shepherd and Margaret Currie (CMN) for the loan of the tillodont

557 fossils from Princeton, B.C. We also thank Brenda Gould of Hedley B.C. for her assistance

558 relocating the Pleasant Valley Mine \#2 site, and Robin Irwin of the Princeton and District

559 Museum and Archives for her cooperation and for putting us in touch with Brenda Gould. The

560 mammalian fossils were imaged by CU-Boulder graduate student Nicole Neu-Yagle in the

561 Entomology Imaging Station of the University of Colorado Museum of Natural History. We

562 thank Deane Bowers and Virginia Scott for use of the Entomology Imaging Station. The

563 manuscript benefited from the careful review and comments of Matthew Mihlbachler and an

564 anonymous reviewer, as well as Associate Editor Hans-Dieter Sues. 
567 Archibald, S.B., Bossert, W.H., Greenwood, D.R., and Farrell, B.D. 2010. Seasonality, the 568 latitudinal gradient of diversity, and Eocene insects. Paleobiology, 36: 374-398. doi:

$569 \quad 10.1666 / 09021.1$

570 Arnold, C.A. 1955a. A Tertiary Azolla from British Columbia. Contributions of the Museum of 571 Paleontology of the University of Michigan, Ann Arbor, 12: 37-45.

572 Arnold, C.A. 1955b. Tertiary conifers from the Princeton coal field of British Columbia.

573 Contributions of the Museum of Paleontology of the University of Michigan, Ann Arbor, $574 \quad 12: 245-258$.

575 Beard, K.C. 1998. East of Eden: Asia as an important center of taxonomic origination in 576 mammalian evolution. In Dawn of the Age of Mammals in Asia. Edited by K.C. Beard 577 and M.R. Dawson. Bulletin of the Carnegie Museum of Natural History, 34: 5-39.

578 Bordet, E., Mihalynuk, M.G., Hart, C.J., Mortensen, J.K., Friedman, R.M., and Gabites, J. 2014. 579 Chronostratigraphy of Eocene volcanism, central British Columbia. Canadian Journal of $580 \quad$ Earth Sciences, 51: 56-103. doi: 10.1139/cjes-2013-0073

581 Bown, T.M., and Kraus, M.J. 1979. Origin of the tribosphenic molar and metatherian and 582 eutherian dental formulae. In Mesozoic Mammals: The First Two-Thirds of Mammalian History. Edited by J.A. Lillegraven, Z. Kielan-Jaworowska, and W.A. Clemens.

Cohen, K.M., Finney, S.C., Gibbard, P.L., and Fan, J.-X. 2013 (updated). The ICS International 586 Chronostratigraphic Chart. Episodes, 36: 199-204. Available from http://www.stratigraphy.org/ICSchart/ChronostratChart2015-01.pdf [accessed 31 $588 \quad$ January 2016]

589 Constenius, K.N., Dawson, M.R., Pierce, H.G., Walter, R.C., and Wilson, M.V.H. 1989. 
Reconnaissance paleontologic study of the Kishenehn Formation, northwestern Montana and southeastern British Columbia. Montana Geologic Society 1989 Field Conference Guidebook. Montana Centennial Edition. Geological Resources of Montana, Vol. 1, pp. 189-203.

594 Cope, E.D. 1883. On the mutual relations of the bunotherian Mammalia. Proceedings of the $595 \quad$ Academy of Natural Sciences of Philadelphia, 35: 77-83.

596 Dawson, G.M. 1877. Report on explorations in the southern portion of British Columbia. 597 Geological Survey of Canada, Report of Progress for 1875-76, pp. 233-265.

598 Dawson, J.W. 1883. On the Cretaceous and Tertiary floras of British Columbia and the Northwest Territory. Proceedings and Transactions of the Royal Society of Canada, Ser.

Dawson, J.W. 1890. On fossil plants from the Similkameen Valley and other places in the Southern Interior of British Columbia. Proceedings and Transactions of the Royal Society of Canada, 8: 75-91.

Dawson, M.R., West, R.M., Langston, W., Jr., and Hutchison, J.H. 1976. Paleogene terrestrial vertebrates: northernmost occurrence, Ellesmere Island, Canada. Science, 192: 781-782. 134.

Dillhoff, R.M. Dillhoff, T.A., Greenwood, D.R., DeVore, M.L., and Pigg, K.B. 2013. The Eocene Thomas Ranch flora, Allenby Formation, Princeton, British Columbia, Canada.

612 Eberle, J.J. 2006. Early Eocene Brontotheriidae (Perissodactyla) from the Eureka Sound Group, 

Ellesmere Island, Canadian High Arctic - implications for brontothere origins and highlatitude dispersal: Journal of Vertebrate Paleontology, 26: 381-386.

615

616

618

619

620

621

622

623

624

625

626

627

628

629

630

631

632

633

634

635

Eberle, J.J., and Eberth, D. A. 2015. Additions to the Eocene Perissodactyla of the Margaret Formation, Eureka Sound Group, Ellesmere Island, Arctic Canada. Canadian Journal of Earth Sciences, 52: 123-133 dx.doi.org/10.1139/cjes-2014-0195.

Eberle, J.J., and Greenwood, D.R. 2012. Life at the top of the greenhouse Eocene world - a review of the Eocene flora and vertebrate fauna from Canada's High Arctic. GSA Bulletin 124: 3-23. doi:10.1130/B30571.1.

Eberle, J.J., Rybczynski, N., and Greenwood, D.R. 2014. Early Eocene mammals from the Driftwood Creek beds, Driftwood Canyon Provincial Park, northern British Columbia. Journal of Vertebrate Paleontology, 34: 739-746. doi: 10.1080/02724634.2014.838175

Fang, J., Wang, Z., and Tang, Z. 2011. Atlas of Woody Plants in China, Distribution and Climate: Vols. 1 \& 2. Higher Education Press/Springer-Verlag, Beijing/Berlin.

Gazin, C.L. 1953. The Tillodontia: an early Tertiary order of mammals. Smithsonian Miscellaneous Collections, 121: 1-110.

Grainger, N.C., Villeneuve, M.E., Heaman, L.M. ,and Anderson, R.G. 2001. New U-Pb and Ar/Ar isotopic age constraints on the timing of Eocene magmatism, Fort Fraser and Nechako River map areas, central British Columbia. Canadian Journal of Earth Sciences, 38: 679-696.

Greenwood, D.R., Archibald, S.B., Mathewes, R.W., and Moss, P.T. 2005. Fossil biotas from the Okanagan Highlands, southern British Columbia and northeastern Washington State: climates and ecosystems across an Eocene landscape. Canadian Journal of Earth Sciences, 42: 167-185. doi:10.1139/e04-100. 
636 Greenwood, D.R., Hill, C.R., and Conran, J.G. 2013. Prumnopitys anglica sp. nov.

637 (Podocarpaceae) from the Eocene of England. Taxon, 62: 565-580. doi: 10.12705/623.15

638 Greenwood, D.R., Pigg, K.B., Basinger, J.F., and DeVore, M.L. 2016a. A review of

639 paleobotanical studies of the Early Eocene Okanagan (Okanogan) Highlands floras of

640 British Columbia, Canada and Washington, U.S.A. Canadian Journal of Earth Sciences,

$641 \quad$ 53(6): 548-564. doi: 10.1139/cjes-2015-0177

642 Greenwood, D.R., Pigg, K.B., and DeVore, M.L. 2016b. Eocene paleontology and geology of

643 western North America. Canadian Journal of Earth Sciences, 53(6): 543-547. doi:

$644 \quad 10.1139 /$ cjes-2016-0043

645 Gunnell, G.F., Bartels, W.S., Gingerich, P.D., and Torres, V. 1992. Wapiti Valley faunas: early

646 and middle Eocene fossil vertebrates from the North Fork of the Shoshone River, Park

647 County, Wyoming. Contributions from the Museum of Paleontology, University of

$648 \quad$ Michigan, 28: 247-287.

649 Harris, A.J., Dee, J., and Palmer, M.W. 2017. The effects of taxonomic rank on climatic

650 calibrations: A test using extant floras of United States counties. Review of Palaeobotany

651 and Palynology, doi: 10.1016/j.revpalbo.2017.02.002.

652 Hills, L.V., and Baadsgaard, H. 1967. Potassium-argon dating of some lower Tertiary strata in

653 British Columbia. Bulletin of Canadian Petroleum Geology, 15: 138-149.

654 Hora, Z.D., and Hancock, K.D. 1994. Quesnel area - Industrial minerals assessment. In

655 Geological Fieldwork 1994, B.C. Ministry of Energy, Mines and Petroleum Resources,

656 Paper 1995-1, pp. 395-404. Available from

657 http://www.empr.gov.bc.ca/Mining/Geoscience/PublicationsCatalogue/Fieldwork/Docum

658 ents/1994/395-404-hora.pdf [accessed 9 February 2017] 
659 Ickert, R.B., Thorkelson, D.J., Marshall, D.D., and Ullrich, T.D. 2009. Eocene adakitic

660 volcanism in southern British Columbia: remelting of arc basalt above a slab window.

661 Tectonophysics, 464: 164-185. doi: 10.1016/j.tecto.2007.10.007

662 Leidy, J. 1871. Remains of extinct mammals from Wyoming. Proceedings of the Academy of $663 \quad$ Natural Sciences of Philadelphia, 23: 113-116.

664 Little, S.A., Stockey, R.A., and Penner, B 2009. Anatomy and development of fruits of 665 Lauraceae from the Middle Eocene Princeton Chert. American Journal of Botany, 96: 637-651. doi: 10.3732/ajb.0800318

667 Lucas, S.G., and Schoch, R.M. 1998. Tillodontia. In Evolution of Tertiary mammals of North America. Vol. 1. Edited by C.M. Janis, K.M. Scott, and L.L. Jacobs. Cambridge

Lucas, S.G., Foss, S.E., and Mihlbachler, M.C. 2004. Achaenodon (Mammalia, Artiodactyla) from the Eocene Clarno Formation, Oregon, and the age of the Hancock Quarry. In Paleogene Mammals. Edited by Lucas, S.G., Zeigler, K.E., and Kondrashov, P.E., New

674 Ludvigsen, R. 2001. The fossils at Driftwood Canyon Provincial Park: A management plan for BC Parks. Available from http://bvcentre.ca/files/External/FossilMgmtPlanLudvigsen2001.pdf [accessed 15 August 2011]

677 Mader, B.J. 1998. Brontotheriidae. In Evolution of Tertiary mammals of North America. Vol. 1. 678 Edited by C.M. Janis, K.M. Scott, and L.L. Jacobs. Cambridge University Press, New 679 York. pp. 525-536.

680 Marsh, O.C. 1873. Notice of new Tertiary mammals. American Journal of Science and Arts, 5: 681 1-9. 
682 Marsh, O.C. 1874. Notice of new Tertiary mammals. III. American Journal of Science and Arts, $683 \quad 7: 531-534$.

684 Massey, N.W.D., MacIntyre, D.G., Desjardins, P.J., and Cooney, R.T. 2005. Digital geology 685 map of British Columbia: whole Province. B.C. Ministry of Forests, Mines and Lands, GeoFile 2005-1. Available from 005-1.aspx [accessed 3 October 2012]

Mathews, W.H., and Monger, J.W.H. 2005. Roadside geology of southern British Columbia. Mountain Press, Missoula, MT.

Mathewes, R.W., Greenwood, D.R. and Archibald, S.B. 2016. Paleoenvironment of the Quilchena flora, British Columbia, during the Early Eocene Climatic Optimum. Canadian Journal of Earth Sciences, 53: 574-590. doi: 10.1139/cjes-2015-0163

McMechan, R.D. 1983. Geology of the Princeton Basin. Paper 1983-3. B.C. Ministry of Energy, Mines and Petroleum Resources, Available from http://www.empr.gov.bc.ca/Mining/Geoscience/PublicationsCatalogue/Papers/Document

698 Mihlbachler, M.C 2007. Eubrontotherium clarnoensis, a new genus and species of brontothere 699 (Brontotheriidae, Perissodactyla) from the Hancock Quarry, Clarno Formation, Wheeler County, Oregon. Paleobios, 27: 19-39.

701 Mihlbachler, M.C. 2008. Species taxonomy, phylogeny, and biogeography of the Brontotheriidae (Mammalia: Perissodactyla). Bulletin of the American Museum of Natural History, 311: $1-475$.

Miller, K.G., Fairbanks, R.G. and Mountain, G.S. 1987. Tertiary oxygen isotope synthesis, sea 
level history, and continental margin erosion. Paleoceanography, 2: 1-19.

706

707

708

709

710

711

712

713

714

715

716

717

718

719

720

721

722

723

724

725

726

727

Miyata, K. 2007a. New material of Asian Trogosus (Tillodontia, Mammalia) from the Akasaki Formation, Kumamoto Prefecture, Japan. Journal of Vertebrate Paleontology, 27: $176-188$.

Miyata, K. 2007b. New species of Trogosus (Tillodontia, Mammalia) from the Green River Basin, Wyoming, USA. Journal of Vertebrate Paleontology, 27: 661-675.

Miyata, K., and Deméré, T.A. 2016. New material of a 'short-faced' Trogosus (Mammalia, Tillodontia) from the Delmar Formation (Bridgerian), San Diego County, California, U.S.A. Journal of Vertebrate Paleontology. DOI: 10.1080/02724634.2016.1089878.

Moss, P.T., Greenwood, D.R., and Archibald, S.B. 2005. Regional and local vegetation community dynamics of the Eocene Okanagan Highlands (British Columbia Washington State) from palynology. Canadian Journal of Earth Sciences, 42: 187-204. doi: $10.1139 / \mathrm{e} 04-095$

Owen, R. 1848. Description of teeth and portions of jaws of two extinct Anthracotherioid quadrupeds (Hyopotamys vectianus and Hyop. bovinus) discovered by the Marchioness of Hastings in the Eocene deposits on the N.W. coast of the Isle of Wight: with an attempt to develop Cuvier's idea of the classification of pachyderms by the number of their toes. Quarterly Journal of the Geological Society of London, 4: 103-141.

Penhallow, D.P. 1908. A report on Tertiary plants of British Columbia, collected by Lawrence M. Lambe in 1906 together with a discussion of previously recorded Tertiary floras. Canada Department of Mines, Geological Survey Branch, No. 1013. 1-167. Ottawa.

Piel, K.M. 1971. Palynology of Oligocene sediments from central British Columbia. Canadian Journal of Botany, 49: 1885-1920. 
728 Pigg, K.B., and DeVore, M.L. 2016. A review of the plants of the Princeton chert (Eocene,

729 British Columbia, Canada). Botany, 94: 661-681. doi: 10.1139/cjb-2016-0079

730 Prothero, D.R., and Emry, R.J. 2004. The Chadronian, Orellan, and Whitneyan North American 731 land mammal ages. In Late Cretaceous and Cenozoic Mammals of North America: Biostratigraphy and Geochronology. Edited by M.O. Woodburne. Columbia University Press, New York, pp. 156-168.

\section{5}

Read, P.B. 1987. Tertiary stratigraphy and industrial minerals, Princeton and Tulameen Basins, British Columbia (NTS 92H/2, 7, 8, 9, 10). Open File 1987-19. Province of British Columbia, Ministry of Energy, Mines and Petroleum Resources, Geological Survey Branch. 1-2. Available from http://webmap.em.gov.bc.ca/mapplace/minpot/Publications_Summary.asp?key=286 [accessed 16 August 2015]

Read, P.B. 2000. Geology of Princeton, Tulameen Basins. Ch. 2. Read, P.B. Geology and Industrial Minerals of the Tertiary Basins, South-Central British Columbia. GeoFile 2000-3. 5-16. Available from http://webmap.em.gov.bc.ca/mapplace/minpot/Publications_Summary.asp?key=156 [accessed 15 October 2012]

Robinson, P. 1966. Fossil Mammalia of the Huerfano Formation, Eocene, of Colorado. Peabody Museum of Natural History, Yale University, Bulletin 21: 1-95.

Robinson, P., Gunnell, G.F., Walsh, S.L., Clyde, W.C., Storer, J.E., Stucky, R.K., Froehlich, D.J., Ferrusquia-Villafranca, I., and McKenna, M.C. 2004. Wasatchian through Duchesnean Biochronology. In Late Cretaceous and Cenozoic Mammals of North America: Biostratigraphy and Geochronology. Edited by M.O. Woodburne. Columbia University 
Press, New York, pp. 106-155.

752 Rose, K.D. 2006. The Beginning of the Age of Mammals. Johns Hopkins University Press,

$753 \quad$ Baltimore, MD.

754 Rouse, G.E., and Mathews, W.H. 1979. Tertiary geology and palynology of the Quesnel area, 755 British Columbia. Bulletin of Canadian Petroleum Geology, 27: 418-445.

756 Russell, L.S. 1935. A middle Eocene mammal from British Columbia. American Journal of $757 \quad$ Science, 29: 54-55.

758 Schoch, R.M. 1986. Systematics, functional morphology and macroevolution of the extinct 759 mammalian Order Taeniodonta. Peabody Museum of Natural History Bulletin, 42: 1-307.

760 Shaw, W.S. 1952. The Princeton Coalfield, British Columbia. Canada Department of Mines and 761 Technical Surveys, Geological Survey of Canada, Paper 52-12. 1-28. Ottawa.

762 Stucky, R.K., and Krishtalka, L. 1983. Revision of the Wind River faunas, early Eocene of 763 central Wyoming. Part 4. The Tillodontia. Annals of the Carnegie Museum, 52: 375-391.

Thompson, R.S., Anderson, K.H., Pelltier, R.T., Strickland, L.E., Bartlein, P.J., and Shafer, S.L. 2012. Quantitative estimation of climatic parameters from vegetation data in North America by the mutual climatic range technique. Quaternary Science Reviews, 51: 18-39.

770 Woodburne, M.O. 2004. Global events and the North American mammalian biochronology. In

771 Late Cretaceous and Cenozoic Mammals of North America: Biostratigraphy and

772 Geochronology. Edited by M.O. Woodburne. Columbia University Press, New York, pp.

773 $315-343$. 
774 Zachos, J.C., Dickens, G.R., and Zeebe, R.E. 2008. An early Cenozoic perspective on

775 greenhouse warming and carbon-cycle dynamics. Nature, 451: 279-283.

776 Zanazzi, A., and Kohn, M.J. 2008. Ecology and physiology of White River mammals based on

777 stable isotope ratios of teeth. Palaeogeography, Palaeoclimatology, Palaeoecology, 257:

$778 \quad 22-37$.

779 Zanazzi, A., Kohn, M. J., MacFadden, B. J., and Terry, D. O. 2007. Large temperature drop

780 across the Eocene-Oligocene transition in central North America. Nature, 445: 639-642.

781 
782 Table 1. List of pollen and spore plant taxa from the Australian Creek Formation (Piel 1971), 783 and additional megaflora listed by Rouse and Mathews (1979). Those with an * were not used in the bioclimatic analysis of the nearest living relatives (NLR).

Palynomorph / major plant type

NLR

Common name

\section{Pteridophytes}

?Equisetum sp.

Equisetum*

horsetail

Lycopodium annotinioides

Lycopodium s.1.*

Club moss

Osmunda claytonites, O. irregulites, $O$.

Osmunda

interrupted fern, royal

regalites

fern

\section{Gymnosperms}

Abies sp.

Abies (Pinaceae)

fir

Cedrus sp. \& C. perialata

Cedrus (Pinaceae)

True cedar

Ephedra sp.

Ephedra*

Mormon tea

Glyptostrobus sp. \& G. vacuipites

Glyptostrobus (Cupressaceae)

Chinese water pine

Metasequoia papillapollenites

Metasequoia (Cupressaceae)

Dawn redwood

Picea sp. 1-3

Picea (Pinaceae)

spruce

Pinus sp. $1 \& 2$

Pinus (Pinaceae)

pine

Podocarpus sp. 1-3

likely Pinaceae*

Pseudotsuga sp.

Pseudotsuga (Pinaceae)

Douglas fir

Sciadopitys serratus

Sciadopitys verticillata

Japanese umbrella pine

Sequoia megafossils

Sequoia sempervirens

California redwood

Taxodium sp., T. kiatipites \& $T$.

Taxodium (Cupressaceae)

Swamp cypress

rousei 
Tsuga sp., T. alexandriana, $T$.

heterophyllites, T. minisacca

Arboreal Angiosperms

Acer sp. $1 \& 2$

Alnus sp. \& A. verus

Betula claripites

Carya juxtaporipites, $C$.

viridifluminipites, $C$.

Castanea sp.

Cercidiphyllum leaf fossils

Corylus sp.

Engelhardia sp. cf. E. chrysolepis

Fagus granulata

Fraxinus sp.\& Fraxinus columbiana

Juglans horniana

Liquidambar sp.

Myrica annulites

Nyssa sp.

Prosopis quesnelli

Pterocarya stellatus

Quercus shiabensis

Tilia crassipites

Ulmus/Zelkova sp. $1 \& 2$
Tsuga (Pinaceae)

Acer (Sapindaceae)

Alnus (Betulaceae)

Betula (Betulaceae)

Carya (Juglandaceae)

Castanea (Fagaceae)

C. japonicum

Corylus (Betulaceae)

Engelhardia (Juglandaceae)

Fagus (Fagaceae)

Fraxinus (Oleaceae)

Juglans (Juglandaceae)

Liquidambar (Altingiaceae)

Myrica (Myricaceae)

Nyssa (Cornaceae)

Prosopis (Fabaceae)*

Pterocarya (Juglandaceae)

Quercus (Fagaceae)

Tilia (Malvaceae)

Ulmus (Ulmaceae)
Hemlock \& western hemlock

maple

alder

birch

hickory or buckeye

chestnut

katsura

hazelnut

beech

ash

walnut

Sweet gum

Sweet gale

Tupelo / sweet gum

mesquite

wing nut

oak

Linden or basswood

elm 
Other Angiosperms

Diervilla echinata Diervilla (Caprifoliaceae)* Bush honeysuckle

?Dorstenia sp. $\quad$ cf. Dorstenia (Moraceae)*

Jussiaea sp. Ludwigia (Onagraceae)* Water primrose

Pachysandra sp. or Sarcococcasp. Pachysandra (Buxaceae)*

Potamogeton narcoslii Potamogeton* Pond weed

(Potamogetonaceae)

Psilastephanocolpites marginatus

?Symplocos sp. cf. Symplocos (Symplocaceae) Yellow wood 
787 Table 2. Tooth measurements (in mm) of CMN 8709, T. latidens from Vermilion Bluffs Shale, $788 \quad$ Allenby Formation, Princeton, B.C.

789

\begin{tabular}{llll}
\hline Element & A-P Length & WTri & WTal \\
\hline Lm1 & 20.8 & 19.2 & 17.2 \\
Lm2 & 23.2 & 23.5 & 21.5 \\
Rm2 & 25.9 & 22.6 & 21.7 \\
Lm3 (incomplete) & $>30$ & 22.8 & 19.4
\end{tabular}

790

791 


\section{Figures}

793 Figure 1. Location maps for the fossil occurrences. (A) Map of North America showing the 794 location of areas outside of British Columbia mentioned in the text. (B) Map of British Columbia showing locations of sites with Eocene mammals reported from British Columbia and other fossil sites mentioned in the text. Nearby cities and towns are shown as solid black circles for reference. Adapted from a map in Greenwood et al. $(2016 b)$.

Figure 2. Chart showing the stratigraphic relationships of the Princeton Group, including the Allenby Formation, and a summary of available radiometric age data for the Princeton Group and the Kamloops Group. (A) K-Ar dates from Allenby Fm. from sources cited in Read (1987, 2000), and (B) from Kamloops Gp. near Quesnel from Rouse \& Mathews (1979). (C) ${ }^{40} \mathrm{Ar}^{39} \mathrm{Ar}$ of Princeton Group volcanics from Ickert et al. (2009). (D) Rock unit relationships adapted from Read (1987, 2000). Minor units and intercalated ash layers not shown. (E) ${ }^{40} \mathrm{Ar}-{ }^{39} \mathrm{Ar}$ and $\mathrm{Pb}-\mathrm{U}$ from tephra reported in Villeneuve and Mathewes (2005), Moss et al. (2005), Archibald et al. (2010), DeVore \& Pigg (2010), and summarized in Greenwood et al. (2016a); A, 48.7 Ma shale; $C$, Hardwick ss. Epoch and Stage chronology from Cohen et al. (2013, updated 2015); NALMA (North American land mammal ages) from Woodburne (2004).

814 Figure 3. Diagrammatic representation of structural and stratigraphic relationships of major 
rock units along the Fraser River Valley near Quesnel. Dashed lines represent minor faults associated with surface slumping of the Miocene Fraser Bend Formation. Dotted lines indicate uncertain relationships. Redrawn from Hora and Hancock (1994). Not to scale.

820 Figure 4. (A-B) Mandibular fragment with worn Lm1-m3 and Rm2 of Trogosus latidens: left lateral (A) and occlusal views (B), respectively; CMN 8709. (C-D) Lm1 talonid fragment and nearly complete Lm2 of Trogosus sp.: occlusal (C) and labial views (D), respectively; CMN 8687. Both CMN 8709 and 8687 are from the Pleasant Valley Mine \#2, Vermilion Bluffs Shale, Allenby Formation, Princeton Basin, B.C. (Bridgerian). Abbreviations: en $=$ entoconid, hyc $=$ hypoconulid, mtst $=$ metastylid; hypoconulid-entoconid basin is indicated by a dashed white line on (C).

Figure 5. Incomplete talonid of Rm 2 and nearly complete $\mathrm{Rm} 3$ referred to Brontotheriina, gen. et. sp. indet.; ROM 6088, from the lower Australian Creek Formation, west side of Fraser River near Quesnel, B.C. Abbreviations: $\mathrm{mtcr}=$ metacristid. 


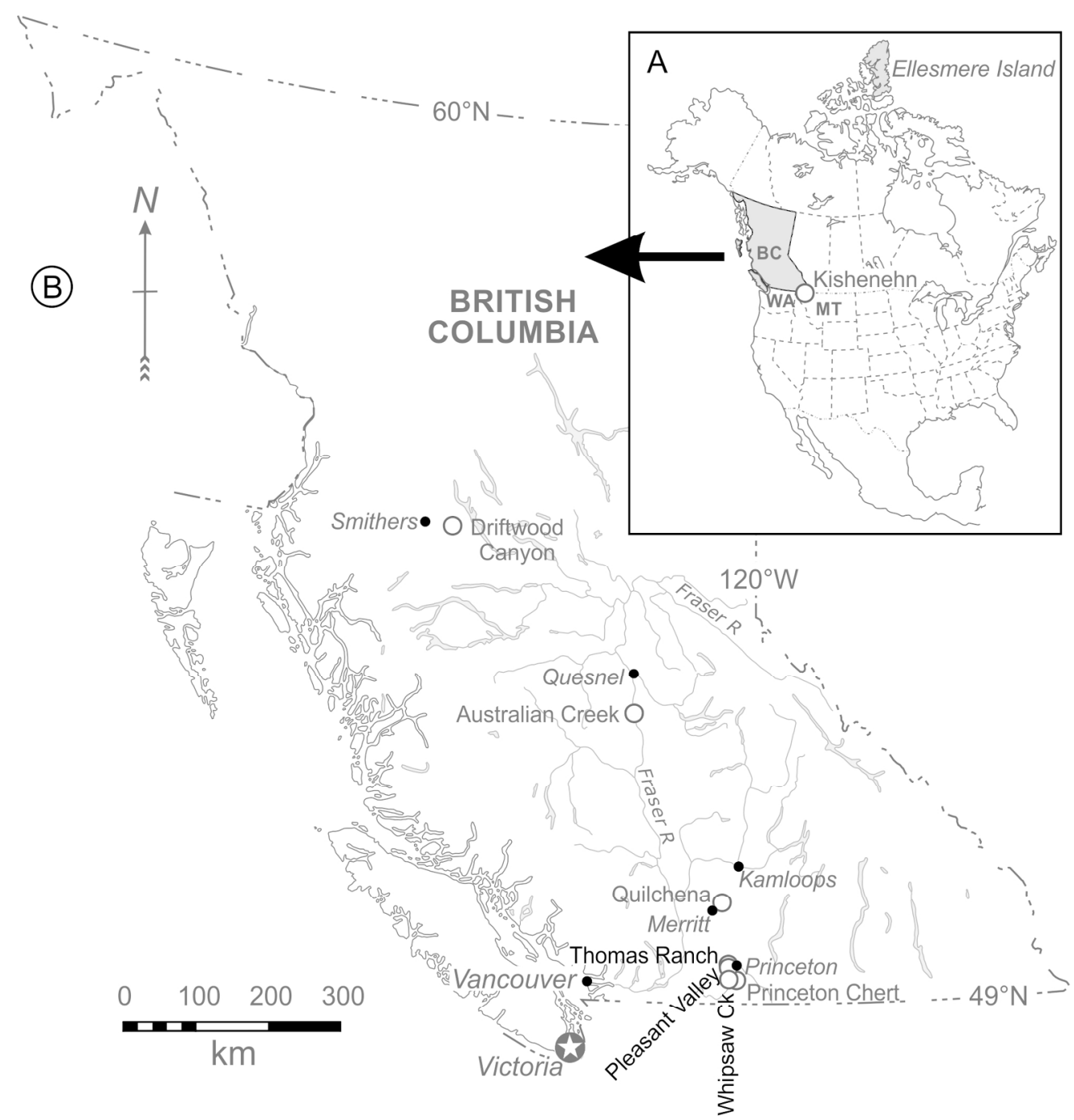

Location maps for the fossil occurrences. (A) Map of North America showing the location of areas outside of British Columbia mentioned in the text. (B) Map of British Columbia showing locations of sites with Eocene mammals reported from British Columbia and other fossil sites mentioned in the text. Nearby cities and towns are shown as solid black circles for reference. Adapted from a map in Greenwood et al. (2016b).

$168 \times 176 \mathrm{~mm}(300 \times 300$ DPI) 


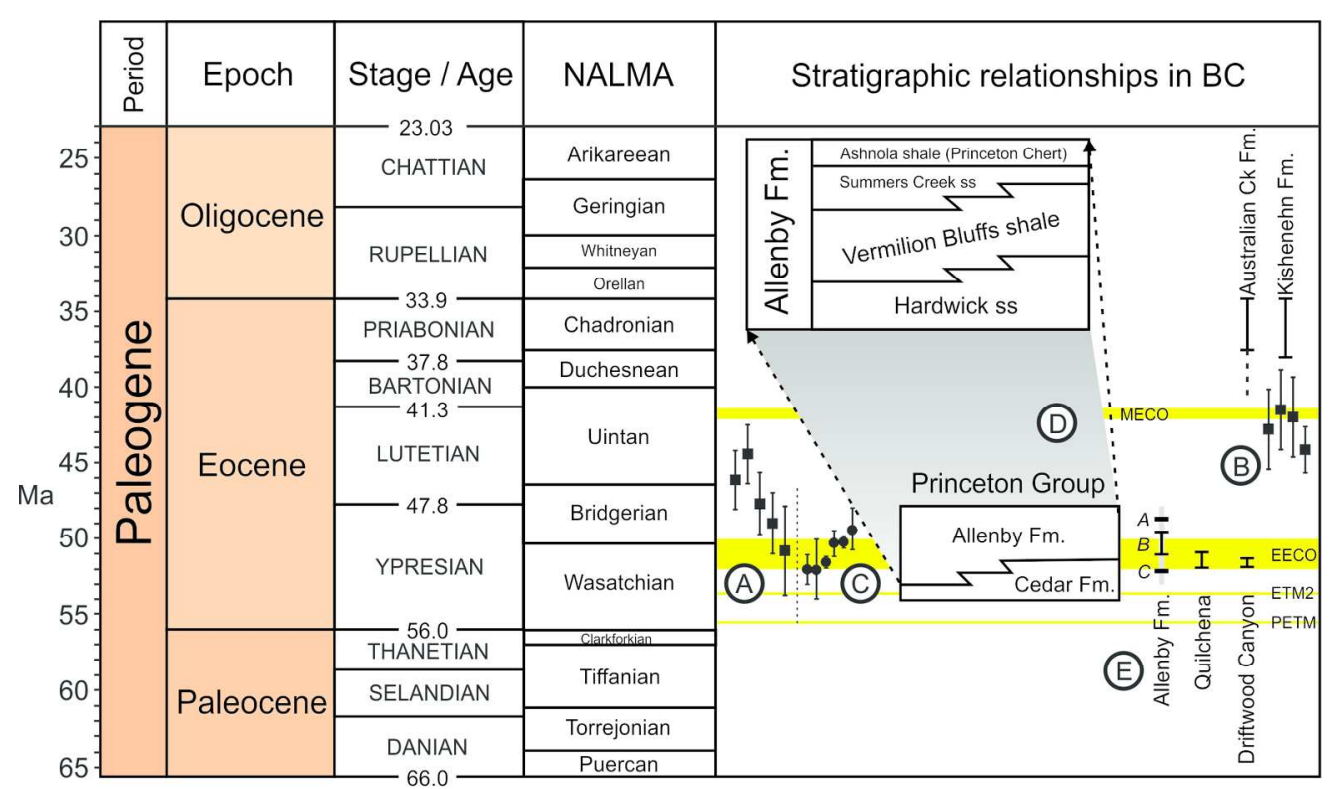

Chart showing the stratigraphic relationships of the Princeton Group, including the Allenby Formation, and a summary of available radiometric age data for the Princeton Group and the Kamloops Group. (A) K-Ar dates from Allenby Fm. from sources cited in Read (1987, 2000), and (B) from Kamloops Gp. near Quesnel from Rouse \& Mathews (1979). (C) 40Ar-39Ar of Princeton Group volcanics from Ickert et al. (2009). (D) Rock unit relationships adapted from Read (1987, 2000). Minor units and intercalated ash layers not shown. (E) 40Ar-39Ar and Pb-U from tephra reported in Villeneuve and Mathewes (2005), Moss et al. (2005), Archibald et al. (2010), DeVore \& Pigg (2010), and summarized in Greenwood et al. (2016a); A, 48.7 Ma from ash layer \#22 from the Ashnola Shale / Princeton Chert; B, Vermilion Bluffs shale; C, Hardwick ss. Epoch and Stage chronology from Cohen et al. (2013, updated 2015); NALMA (North American land mammal ages) from Woodburne (2004). Adapted from a figure in Greenwood et al. (2016b).

$172 \times 102 \mathrm{~mm}(300 \times 300 \mathrm{DPI})$ 


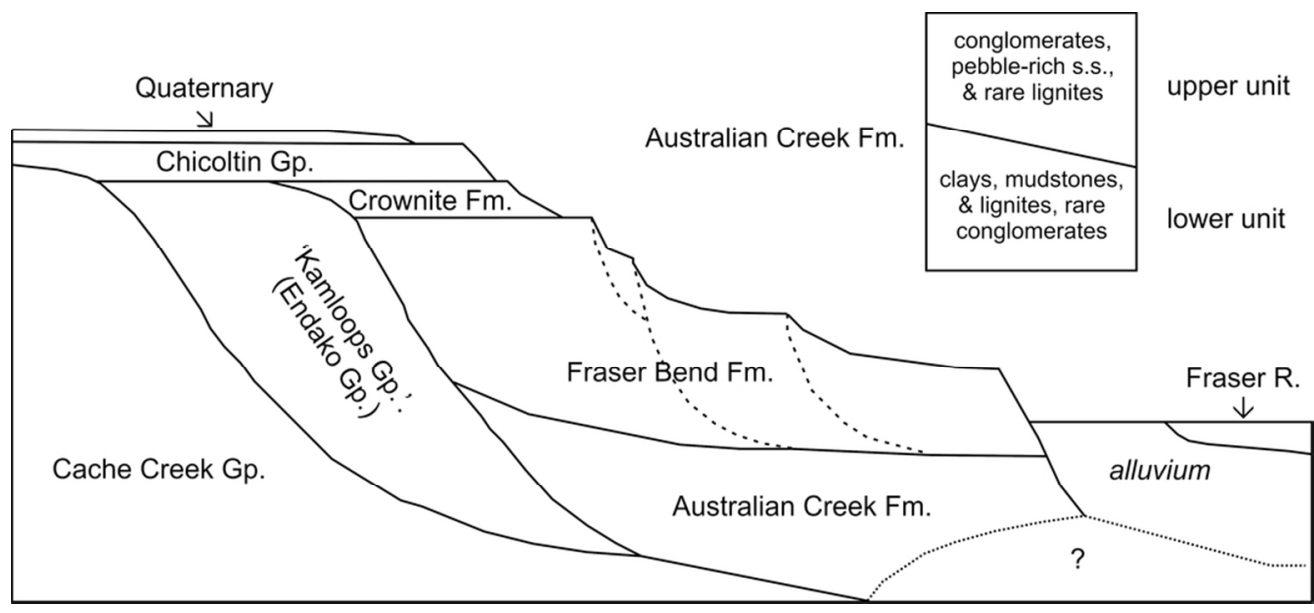

Diagrammatic representation of structural and stratigraphic relationships of major rock units along the Fraser River Valley near Quesnel. Dashed lines represent minor faults associated with surface slumping of the Miocene Fraser Bend Formation. Dotted lines indicate uncertain relationships. Redrawn from Hora and Hancock (1994). Not to scale.

$90 \times 41 \mathrm{~mm}(300 \times 300 \mathrm{DPI})$ 

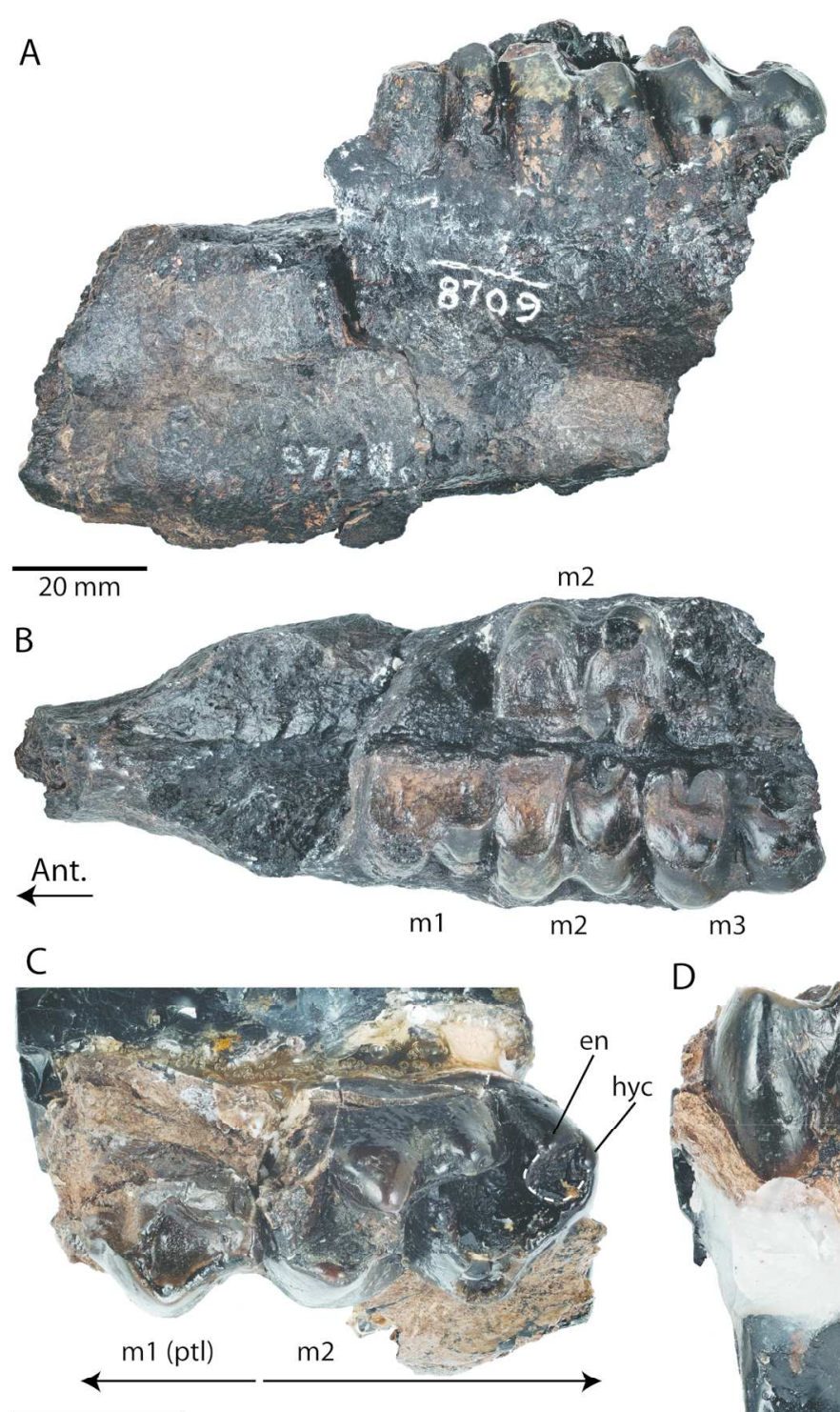

$10 \mathrm{~mm}$

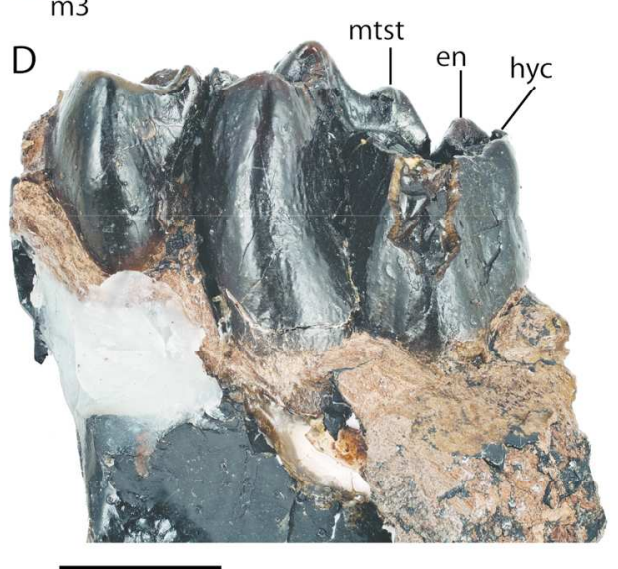

$10 \mathrm{~mm}$

(A-B) Mandibular fragment with worn Lm1-m3 and Rm2 of Trogosus latidens: left lateral (A) and occlusal views (B), respectively; CMN 8709. (C-D) Lm1 talonid fragment and nearly complete Lm2 of Trogosus sp.: occlusal (C) and labial views (D), respectively; CMN 8687. Both CMN 8709 and 8687 are from the Pleasant Valley Mine \#2, Vermilion Bluffs Shale, Allenby Formation, Princeton Basin, B.C. (Bridgerian). Abbreviations: en = entoconid, hyc = hypoconulid, mtst = metastylid; hypoconulid-entoconid basin is indicated by a dashed white line on (C).

$182 \times 219 \mathrm{~mm}(300 \times 300 \mathrm{DPI})$ 


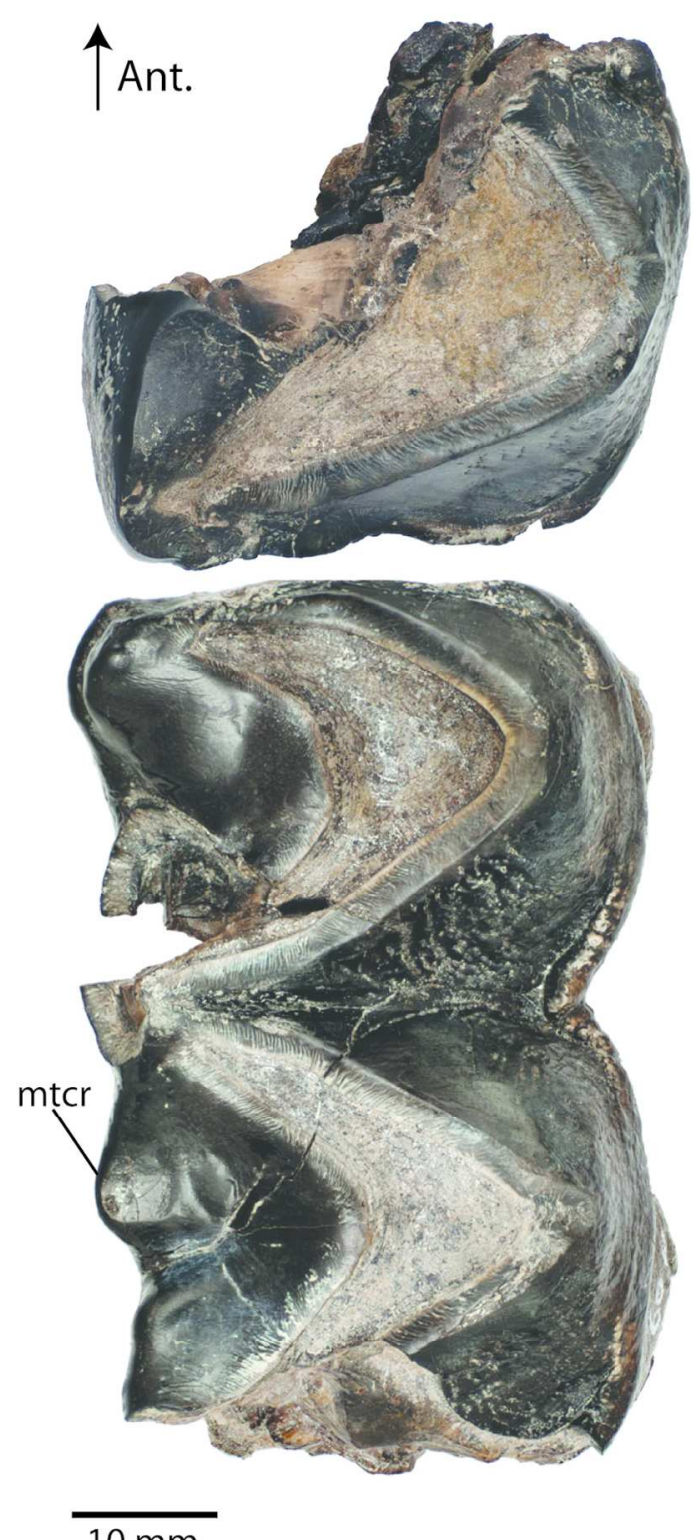

Incomplete talonid of Rm2 and nearly complete Rm3 referred to Brontotheriina, gen. et. sp. indet.; ROM 6088 , from the lower Australian Creek Formation, west side of Fraser River near Quesnel, B.C. Abbreviations: $\mathrm{mtcr}=$ metacristid.

$86 \times 190 \mathrm{~mm}(300 \times 300 \mathrm{DPI})$ 